\title{
PENGARUH MODEL PEMBELAJARAN PBL BERBANTUAN ALAT PERAGA DALAM PENINGKATAN KEMAMPUAN PENALARAN MATEMATIS
}

\author{
Oleh : \\ Richa Aulya 1) , Jayanti Putri Purwaningrum 2) \\ 1. Fakultas Keguruan dan Ilmu Pendidikan, Universitas Muria Kudus \\ 2. Fakultas Keguruan dan Ilmu Pendidikan, Universitas Muria Kudus
}

\begin{abstract}
Abstrak
Dalam pembelajaran matematika, kemampuan penalaran matematis siswa bersifat penting dikarenakan pembelajaran tersebut lebih ditekankan pada suatu aktivitas pemecahan masalah dan penalaran yang sangat erat serta berkaitan dengan pencapaian prestasi siswa. Namun, pada kondisi saat ini, penalaran matematis siswa dalam pembelajaran matematika masih dianggap kurang dan belum menekankan secara khusus. Penalaran matematis siswa yang masih rendah perlu diperbaiki dalam proses pembelajaran matematika. Ada beberapa cara untuk melatih siswa dalam bernalar yakni dengan menggunakan model pembelajaran dan alat peraga. Model pembelajaran yang dapat meningkatkan kemampuan penalaran matematis siswa agar menjadikan situasi belajar menyenangkan dan membuat siswa tidak merasa bosan yakni model pembelajaran problem based learning (PBL). Dengan menggabungkan model problem based learning dan alat peraga dapat meningkatkan kemampuan matematis siswa sehingga dapat tercapainya tujuan pembelajaran dan siswa tidak hanya sekedar menghafal melainkan juga memahami materi pelajaran.
\end{abstract}

Kata kunci-Kemampuan Penalaran Matematis, Model Problem Based Learning, Alat Peraga

\begin{abstract}
In learning mathematics, students' mathematical reasoning ability is important because the learning is more emphasized on a problem-solving and reasoning activity that is very closely related to student achievement. However, in the current condition, students' mathematical reasoning in learning mathematics is still considered lacking and has not been emphasized specifically. The students' low mathematical reasoning needs to be improved in the mathematics learning process. There are several ways to train students in reasoning, namely by using learning models and teaching aids. A learning model that can improve students' mathematical reasoning abilities to make learning situations fun and make students not feel bored is the problem based learning (PBL) learning model. By combining problem based learning models and teaching aids, it can improve students' mathematical abilities so that learning objectives can be achieved and students not only memorize but also understand the subject matter.
\end{abstract}

Keywords - Mathematical Reasoning Ability, Problem Based Learning Model, Teaching Aid

\section{PENDAHULUAN}

Wabah COVID-19 muncul pertama kali di Kota Wuhan di Negara Cina. Penyebarannya sangat cepat dan mematikan (Syafrida, 2020). Di Indonesia sendiri COVID-19 menyebar sejak awal bulan Maret di Jakarta dan jumlah kasusnya terus bertambah untuk setiap harinya. Meningkatnya jumlah angka kematian memunculkan dampak di seluruh sektor kehidupan masyarakat tanpa terkecuali pada sektor pendidikan. Kebijakan-kebijakan yang dikeluarkan oleh pemerintah Indonesia dalam rangka mengatasi dampak dari COVID-19 yakni tidak melakukan kegiatan belajar mengajar seperti biasa melainkan melalui pembelajaran daring bagi seluruh institusi pendidikan (Wargadinata et al., 2020)

Pendidikan merupakan suatu proses yang dapat merubah pola pikir melalui pelatihan dan pengajaran guna menambah wawasan supaya siswa lebih aktif dalam pengembangan pola pikirnya (Putri et al., 2019). Pendidikan merupakan salah satu konsep dan cara untuk mewujudkan sistem pembelajaran dan situasi agar siswa bisa mengembangkan kemampuan dalam dirinya agar aktif dalam ketrampilan, kecerdasan, kekuatan spiritual, kepribadian, dan akhlak mulia guna mempercerdas kehidupan berbangsa dan bernegara yang tercantum ke dalam Undang-Undang Sistem Pendidikan Nasional Nomor 20 Tahun 2003 (Putri et al., 2019). Pendidikan sangat mempunyai peran penting untuk memajukan suatu negara. 
Dengan adanya pendidikan dapat menciptakan sumber daya manusia yang memiliki jiwa kompeten sehingga dapat menunjang kemajuan negara (Nababan, 2020).

Sistem pendidikan yang ada di Indonesia terdapat kesenjangan antara realita dan keinginan (Putri et al., 2019). Secara makro terlihat pada aspek pengelolaan, materi ajar atau kurikulum, peran dari masyarakat dan pemerintah, sumber daya manusia, metodologi pembelajaran dan pendekatan, lingkungan sekolah atau kampus, akreditasi, dan dana. Kesenjangan itulah yang disebabkan karena faktor ekonomi, sosial budaya, politik dan lainnya yang sering berganti sesuai dengan perkembangan dan perubahan zaman.

Matematika merupakan suatu ilmu yang berperan penting pada perkembangan kehidupan manusia. Matematika merupakan suatu proses bernalar, pembentukan sikap jujur, objektif, kritis, sistematis, dan kreatif, pembentukan pola pikir dan karakter serta ilmu yang dapat menunjang pada pengambilan kesimpulan (Putri et al., 2019). Di Indonesia perkembangan pendidikan matematika sejalan dengan berkembangnya pendidikan matematika yang ada di dunia. Namun, berkembangnya pembelajaran matematika di Indonesia tidak sejalan dengan peningkatan kemampuan yang dimiliki siswa pada pelajaran matematika. Hal tersebut bisa ditunjukkan dari kemampuan siswa dalam menemukan pola, hubungan, dan sifat yang ada dalam mempelajari materi matematika yang dirasa masih kurang. Padahal ketika mereka dapat melakukan hal tersebut, maka mereka mampu untuk memahami permasalahan matematika dengan cara melihat suatu bukti dari suatu penyelesaian matematika dengan baik. Kemampuan itulah yang disebut dengan kemampuan penalaran matematis (Abidah et al., 2021).

Kemampuan matematis memiliki peran pada pengasahan proses berpikir siswa guna mengkomunikasikan ide-ide yang matematis yakni kemampuan penalaran matematis. Berdasarkan tujuan dalam pembelajaran matematika, aspek dalam pengembangan kemampuan penalaran matematis siswa sudah memperhatikan kurikulum yang sudah tersusun. Namun, pada kondisi saat ini kemampuan penalaran matematis siswa dalam pembelajaran matematika di sekolah dianggap kurang dan tidak menekankan secara khusus (Cahyani, 2019). Hal tersebut dapat terlihat melalui laporan dari survei yang dilakukan oleh TIMSS dan PISA yang memperlihatkan kurangnya rata-rata nilai matematis siswa di Indonesia. Hasil survei TIMSS pada tahun 2015 memperlihatkan prestasi matematika siswa di Indonesia menempati peringkat 44 dari 49 negara (IEA, 2016). Sedangkan hasil dari studi PISA pada tahun 2015 memperlihatkan kemampuan matematika yang dimiliki siswa Indonesia ada di peringkat 63 dari 70 negara (OECD, 2016).

Berdasarkan fakta tersebut maka dengan menyikapi suatu permasalahan mengenai penalaran matematis siswa yang masih kurang sehingga perlu dilakukan perbaikan pada proses pembelajaran matematika. Ada beberapa hal yang dapat dilakukan guna melatih siswa dalam bernalar yakni dengan menggunakan model pembelajaran dan alat peraga. Model pembelajaran yang dapat meningkatkan kemampuan penalaran matematis siswa agar menjadikan situasi belajar menyenangkan dan membuat siswa tidak merasa bosan yakni model pembelajaran problem based learning (PBL) maka tujuan dari pembelajaran bisa tercapai dan siswa tidak sekedar menghafal tetapi memahami juga materi pembelajaran. Salah satu model pembelajaran yang dapat mengembangkan keterampilan siswa dalam berpikir (komunikasi, penalaran, dan koneksi) untuk memecahkan masalah merupakan Problem Based Learning (PBL) (Nababan, 2020).

Problem based learning (PBL) merupakan model pembelajaran yang telah disesuaikan dengan kurikulum 2013. Hal tersebut menunjukkan bahwa problem based learning atau pembelajaran berbasis masalah dapat dijadikan alternatif pada guru agar dapat mencapai tujuan pembelajarannya (Munir \& Sholehah, 2019). Selain melalui pembelajaran berbasis masalah, guru juga harus memiliki strategi untuk menerapkan pembelajaran berbasis masalah tersebut agar dapat memfasilitasi siswa dalam memperoleh konsepnya sendiri dan meningkatkan kemampuan penalaran matematisnya. Suatu strategi untuk menerapkan pembelajaran berbasis masalah oleh guru adalah dengan berbantuan alat peraga.

Alat peraga merupakan alat yang dipergunakan dalam menjelaskan konsep dalam matematika (Cahyani, 2019). Alat peraga tersebut merupakan alat bantu yang dapat digunakan guna melancarkan proses pembelajaran matematika. Alat peraga diharapkan agar siswa bisa mengerti konsep dengan baik, maka dari itu dalam pembelajaran siswa diberikan kesempatan mengkonstruksi pengetahuan dirinya sendiri melalui alat peraga. Maka dari itu dengan adanya alat peraga, guru lebih mudah menerapkan pembelajaran berbasis masalah sehingga kemampuan penalaran matematis siswanya dapat ditingkatkan.

\section{METODE PENELITIAN}

Metode yang dipergunakan dalam penelitian ini ialah dengan metode penelitian kepustakaan yakni penelitian yang dilakukan hanya berdasarkan pada karya tertulis, termasuk pada hasil penelitian yang 
ISSN. 2621-9832

JURNAL MathEdu (Mathematic Education Journal) http://journal.ipts.ac.id/index.php/MathEdu

Vol. 4. No. 3 November 2021

telah dipublikasikan maupun yang belum dipublikasikan. Penelitian ini memuat teori atau gagasan yang saling berkaitan secara erat dan didukung dengan data-data dari beberapa sumber pustaka.

\section{HASIL DAN PEMBAHASAN \\ KEMAMPUAN PENALARAN MATEMATIS SISWA}

Kemampuan penalaran matematis merupakan kemampuan yang dimiliki oleh siswa dalam membuktikan dan menyimpulkan suatu pernyataan, membuat gagasan baru, hingga menyelesaikan masalah dalam matematika (Nababan, 2020). Kemampuan penalaran matematis siswa sangat diperlukan guna mencapai hasil belajar dalam pembelajaran matematika dengan baik. Meningkatnya kemampuan siswa dalam bernalar pada proses pembelajaran sangat dibutuhkan untuk mencapai suatu keberhasilan. Maka dari itu, siswa harus dikembangkan dan dibiasakan dalam kemampuan penalaran matematis untuk setiap pembelajaran matematika. Melalui bernalar, siswa diharapkan mampu menunjukkan bahwa matematika merupakan suatu kajian yang logis atau masuk akal, sehingga siswa dapat yakin bahwa matematika dapat dipikirkan, dipahami, dibuktikan, dan dievaluasi.

Penalaran dibagi menjadi dua yakni penalaran induktif dan deduktif (Nababan, 2020). Penalaran induktif merupakan proses berpikir dengan membuat pernyataan baru dari kasus yang bersifat khusus atau pengambilan kesimpulan yang bersifat umum. Penalaran deduktif merupakan suatu penarikan kesimpulan yang bersifat umum menuju khusus dengan melihat fakta yang sudah ada. Berdasarkan hal tersebut maka dapat disimpulkan bahwa penalaran matematis merupakan proses, kegiatan atau aktivitas dalam berpikir guna membuat pernyataan baru dengan benar yang dapat diketahui sebelumnya atau penarikan kesimpulan menggunakan suatu cara yang logis baik pada penalaran induktif maupun penalaran deduktif.

Menurut (Nababan, 2020), penalaran matematis secara garis besar dapat tergolong menjadi dua yakni sebagai berikut:

1. Penalaran induktif merupakan penalaran dari suatu kasus kemudian diambil kesimpulannya yang bersifat lebih umum. Penalaran tersebut dapat membantu siswa dalam memudahkan melakukan pemetaan masalah sehingga penalaran ini dapat dipakai dalam suatu masalah yang serupa. Berikut beberapa penalaran induktif diantaranya adalah: penalaran generalisasi, analogi, menyusun konjektur, memperkirakan proses solusi dan jawaban atau estimasi. Penalaran tersebut digolongkan kepada berfikir matematis dengan tingkat tinggi atau rendah.

2. Penalaran deduktif merupakan suatu proses penalaran dari pengalaman umum atau pengetahuan prinsip yang dapat menuntun kita pada kesimpulan untuk sesuatu yang bersifat khusus. Berikut berapa penalaran deduktif yakni: menarik kesimpulan yang logis, melakukan operasi perhitungan, memberikan penjelasan terhadap sifat, fakta, model, pola atau hubungan.

\section{MODEL PEMBELAJARAN PROBLEM BASED LEARNING}

Menurut (Shofiyah et al., 2018), model pembelajaran problem based learning merupakan suatu kurikulum yang merencanakan pembelajaran guna mencapai tujuan instuksional. PBL (Problem based learning) merupakan model pembelajaran yang dapat menginisiasi siswa dengan cara menghadirkan suatu masalah untuk diselesaikan oleh siswa. Dalam proses pemecahan masalah, siswa dapat mengembangkan keterampilan self-regulated learner dan keterampilan dalam memecahkan masalah serta membangun pengetahuan.

Menurut (Shofiyah et al., 2018), mengatakan bahwa problem based learning (PBL) memiliki ciri-ciri sebagai berikut:

1. Fokus terhadap interdisiplin

Masalah yang dihadapkan dalam pembelajaran kepada siswa walaupun hanya terdapat dalam masalah pembelajaran tertentu maka solusi yang diharapkan mempengaruhi banyak mata pelajaran.

2. Penyelidikan otentik

Model pembelajaran problem based learning membuat siswa untuk mengikuti penyelidikan yang otentik sehingga siswa dapat menghasilkan pemecahan yang nyata pada masalah yang nyata pula. Siswa diminta melakukan analisis informasi, eksperimen, membuat inferensi dan kesimpulan.

3. Menghasilkan dan memamerkan karya nyata

Model problem based learning menghasilkan suatu produk dalam bentuk suatu karya nyata dan memamerkannya. Hasil produk tersebut mewakili solusi yang berupa laporan, sinetron, model fisik, program komputer atau rekaman video yang dirancang dan dibahas untuk dikomunikasikan lebih lanjut kepada pihak terkait.

4. Kolaborasi 
Siswa melakukan kerja sama dengan siswa lain dalam satu kelompok sehingga mendatangkan motivasi untuk menambah kesempatan dalam berbagi dialog dan inkuiri, terlibat dalam tugas yang kompleks dan untuk mengembangkan keterampilan sosial.

Sintaks dalam model pembelajaran problem based learning secara umum sebagai berikut:

\begin{tabular}{|c|c|}
\hline Tahap atau Fase & Perilaku Guru \\
\hline $\begin{array}{l}\text { Fase } 1 \\
\text { Orientasi siswa } \\
\text { terhadap masalah }\end{array}$ & $\begin{array}{l}\text { Guru memberikan informasi mengenai tujuan dari } \\
\text { pembelajaran, melakukan deskripsi suatu kebutuhan } \\
\text { logistik, dan memberikan motivasi supaya siswa dapat } \\
\text { terlibat ke dalam aktivitas pemecahan masalah yang } \\
\text { siswa pilih sendiri. }\end{array}$ \\
\hline $\begin{array}{l}\text { Fase } 2 \\
\text { Mengorganisasi } \\
\text { siswa dalam belajar }\end{array}$ & $\begin{array}{l}\text { Siswa mendapat bantuan dari guru dalam mengatur } \\
\text { dan menentukan tugas yang berkaitan dengan masalah } \\
\text { yang dipilih. }\end{array}$ \\
\hline $\begin{array}{l}\text { Fase } 3 \\
\text { Membantu dalam } \\
\text { hal melaksanakan } \\
\text { penyelidikan }\end{array}$ & $\begin{array}{l}\text { Siswa mendapat bantuan dari guru untuk melakukan } \\
\text { eksperimen, mengumpulkan suatu informasi, dan } \\
\text { mencari solusi dan penjelasan. }\end{array}$ \\
\hline $\begin{array}{l}\text { Fase } 4 \\
\text { Hasil karya sendiri } \\
\text { disajikan } r \text { dan } \\
\text { dikembangkan serta } \\
\text { dipamerkan }\end{array}$ & $\begin{array}{l}\text { Siswa mendapat bantuan dari guru untuk menyiapkan } \\
\text { dan merencanakan hasil karya siswa yang tepat seperti } \\
\text { halnya laporan. }\end{array}$ \\
\hline $\begin{array}{l}\text { Fase } 5 \\
\text { Melakukan analisis } \\
\text { dan evaluasi dalam } \\
\text { proses pemecahan } \\
\text { masalah }\end{array}$ & $\begin{array}{l}\text { Siswa mendapat bantuan dari guru dalam } \\
\text { melaksanakan penyelidikan atau refleksi serta proses } \\
\text { yang digunakan. }\end{array}$ \\
\hline
\end{tabular}

Menurut (Yulianti \& Gunawan, 2019), kelebihan dalam model pembelajaran problem based learning sebagai berikut:

1. Pemecahan masalah selama proses pembelajaran berlangsung menantang kemampuan yang dimiliki siswa dan memberikan kepuasan tersendiri kepada siswa.

2. Pemecahan masalah selama proses pembelajaran cukup baik guna memahami isi dari pelajaran.

3. Membantu siswa dalam proses mentransfer untuk memahami masalah yang berada dalam kehidupan sehari-hari.

4. Model pembelajaran problem based learning dapat meningkatkan kualitas dari aktivitas belajar.

5. Memberikan bantuan kepada siswa dalam mengembangkan pengetahuan dan memberikan bantuan kepada siswa untuk bertanggung jawab pada pembelajarannya sendiri.

6. Menciptakan suasana belajar yang mengasyikkan sehingga disukai oleh siswa.

7. Memberikan bantuan kepada siswa dalam memahami hakekat belajar bukan hanya mengetahui pembelajaran berdasarkan teks.

8. Memberikan rangsangan kepada siswa untuk belajar secara kontinu.

9. Memberikan kemungkinan aplikasi dalam dunia nyata.

Menurut (Yulianti \& Gunawan, 2019), kekurangan dalam model pembelajaran problem based learning sebagai berikut:

1. Model pembelajaran problem based learning membutuhkan waktu yang cukup dalam persiapannya.

2. Ketika siswa mengalami kesulitan atau rasa kurang percaya diri dan minat yang rendah maka siswa tersebut enggan dalam mencoba kembali.

3. Pemahaman yang dirasa kurang dalam memecahkan masalah membuat siswa kurang termovitasi untuk belajar.

\section{ALAT PERAGA}

Alat peraga pada pembelajaran matematika merupakan benda yang dapat diraba, diamati, dan digerakkan sehingga dapat digunakan oleh guru guna menyampaikan keterampilan atau konsep saat proses mengajar matematika. Alat peraga dibagi menjadi dua jenis yakni alat peraga sederhana dan tidak sederhana. Alat peraga sederhana yakni dapat berupa buatan dari guru sedangkan alat peraga yang tidak sederhana misalnya alat peraga buatan pabrik. 
Alat peraga memiliki fungsi untuk memperagakan atau menerangkan suatu pelajaran dalam proses pembelajaran. Dalam proses pembelajaran guru dituntut mampu untuk menjelaskan suatu konsep kepada siswanya. Usaha tersebut bisa dibantuk dengan menggunakan alat peraga matematika, karena dengan alat peraga tersebut konsep akan lebih mudah untuk dipahami (Firmiana et al., 2014).

Dengan adanya alat peraga matematika, siswa lebih mudah dalam memahami hubungan antara lingkungan alam sekitar dengan matematika. Siswa lebih mudah memahami fungsi matematika dalam kehidupan sehari-hari. Maka dengan adanya kesadaran ini diharapkan mendorong siswa untuk mendalami dalam mempelajari matematika. Misalnya dengan menggunakan alat peraga dalam konsep bangun ruang dimensi tiga, siswa akan menjadi lebih tertarik dalam proses pembelajarannya sehingga dapat menyadari dan menemukan hubungan antara lingkungan sekitar dengan matematika. Dalam penggunaanya alat peraga wajib dilaksanakan dengan cermat sehingga tidak timbul konsep yang lebih rumit akibat penggunaan alat peraga. Alat peraga juga diharuskan digunakan secara tepat sesuai dengan materi yang diajarkan, perkembangan mental anak dan metode pembelajaran yang digunakan.

\section{KEMAMPUAN PENALARAN MATEMATIS MELALUI PBL DENGAN BERBANTUAN ALAT PERAGA}

Pentingnya kemampuan penalaran matematis dalam pembelajaran matematika dikarenakan pembelajaran tersebut lebih ditekankan pada suatu aktivitas pemecahan masalah dan penalaran yang sangat erat dan berkaitan dengan pencapaian prestasi siswa (Munir \& Sholehah, 2019). Hal tersebut mempunyai arti bahwa penalaran dalam pembelajaran matematika dapat dijadikan fondasi guna membangun pengetahuan dalam pelajaran matematika. Matematika merupakan suatu kreasi dari dalam pemikiran manusia yang berhubungan erat dengan penalaran dan proses-proses ide. Maka dari itu, sebagai guru diharapkan dapat membantu siswanya dalam pengembangan penalaran matematis siswa.

Menurut (Munir \& Sholehah, 2019), menyatakan bahwa hasil dari penelitian yang dilakukannya mengenai peningkatan kemampuan penalaran matematis siswa dengan model pembelajaran problem based learning yang diterapkannya bersifat cukup efektif. Selain itu, dengan diterapkannya model pembelajaran problem based learning mendapat respon yang cukup positif dari siswa.

Sama halnya seperti (Abidah et al., 2021) yang melaksanakan penelitian mengenai peningkatan kemampuan penalaran matematis siswa SMP Negeri 176 Jakarta kelas VII-1 dengan menggunakan problem based learning sebagai model pembelajarannya dinyatakan berhasil berdasarkan pembelajaran siklus 3. Hasil perolehan rata-rata nilai tes akhir pada siklus 3 mencapai 84,97 dengan kategori sangat baik. Selain itu, dalam pembelajaran siklus 3 ini, diraih sebesar 75\% dari total siswa secara keseluruhan atau 27 siswa berhasil mendapatkan kategori yang baik dengan perolehan nilai minimal lebih dari atau sama dengan 76 pada kategori penalaran matematis siswa. Maka dari itu, penerapan model problem based learning dapat lebih unggul dalam peningkatan kemampuan penalaran matematis siswa daripada model konvensional yang diterapkan oleh guru sebelumnya. Model pembelajaran problem based learning bisa melatih kemampuan siswa untuk menyelesaikan masalah dengan berpikir logis yang disebut juga melaksanakan penalaran matematis dari model pembelajaran problem based learning.

Selain itu menurut hasil penelitian (Cahyani, 2019), peningkatan kemampuan penalaran matematis siswa dengan melakukan analisis data kualitatif dan kuantitatif dapat disimpulkan bahwa terjadi peningkatan kemampuan penalaran matematis siswa berbantuan alat peraga yang dapat dilihat dari perbedaan hasil yang signifikan antara pre-test dan post-test. Dalam pre-test atau kemampuan awal pada kelas eksperimen, penalaran matematis siswa memperoleh nilai tertinggi 47 dan nilai terendah sebesar 18 dengan nilai rata-ratanya mencapai 26,00. Sedangkan berbeda sekali dengan hasil post test atau kemapuan akhir pada kelas eksperimen. Penalaran matematis siswa memperoleh nilai tertinggi mencapai 92 dan nilai terendah sebesar 65 dengan nilai rata-ratanya 78,00. Dari hasil tersebut dapat disimpulkan bahwa dengan adanya alat peraga dapat meningkatkan kemampuan matematis siswa. Maka dari itu upaya peningkatan kemampuan penalaran matematis siswa dapat dilakukan dengan menggunakan model pembelajaran problem based learning dengan berbantuan alat peraga sehingga dengan menggabungkan kedua hal penting tersebut dapat bersifat efektif untuk meningkatkan kemampuan penalaran siswa.

\section{KESIMPULAN \\ Kesimpulan}

Kemampuan penalaran matematis merupakan kemampuan yang dimiliki oleh siswa dalam membuktikan dan menyimpulkan suatu pernyataan, membuat gagasan baru, hingga menyelesaikan masalah dalam matematika. Pentingnya kemampuan penalaran matematis dalam pembelajaran matematika dikarenakan pembelajaran tersebut lebih ditekankan pada suatu aktivitas pemecahan 
masalah dan penalaran yang sangat erat dan berkaitan dengan pencapaian prestasi siswa. Namun, pada kondisi saat ini kemampuan penalaran matematis siswa dalam pembelajaran matematika di sekolah masih dianggap rendah dan belum menekankan secara khusus. Hal tersebut dapat terlihat melalui laporan dari survei yang dilakukan oleh TIMSS dan PISA yang memperlihatkan kurangnya rata-rata nilai matematis siswa di Indonesia. Hasil survei TIMSS pada tahun 2015 memperlihatkan prestasi matematika siswa di Indonesia menempati peringkat 44 dari 49 negara (IEA, 2016). Sedangkan hasil dari studi PISA pada tahun 2015 memperlihatkan kemampuan matematika yang dimiliki siswa Indonesia ada di peringkat 63 dari 70 negara (OECD, 2016).

Penalaran matematis siswa yang masih kurang perlu dilakukan perbaikan dalam proses pembelajaran matematika. Ada beberapa cara untuk melatih siswa dalam bernalar yakni dengan menggunakan model pembelajaran dan alat peraga. Model pembelajaran yang dapat meningkatkan kemampuan penalaran matematis siswa agar menjadikan situasi belajar menyenangkan dan membuat siswa tidak merasa bosan yakni model pembelajaran problem based learning (PBL). Dengan menggabungkan model problem based learning dan alat peraga dapat meningkatkan kemampuan matematis siswa sehingga tujuan dari pembelajaran bisa tercapai dan siswa tidak hanya sekedar menghafal tetapi juga memahami materi pembelajaran.

\section{Saran}

Dalam penulisan artikel ini dirasa masih banyak kekurangan sehingga tidak sesuai dengan keinginan para pembaca, maka dari itu masih diperlukan penelitian untuk menyempurnakan hasil penilitian artikel ini supaya berdaya guna.

\section{REFERENSI}

Abidah, N., Hakim, L. El, \& Wijayanti, D. A. (2021). Upaya Meningkatkan Kemampuan Penalaran Matematis Siswa melalui Model Problem Based Learning pada Materi Aritmetika Sosial. 3(1), 5866.

Cahyani, P. A. (2019). KEMAMPUAN PENALARAN MATEMATIS PESERTA DIDIK MELALUI MODEL PEMBELAJARAN RECIPROCAL TEACHING DENGAN BERBANTUAN ALAT PERAGA “ KARTU PINTAR ” PADA MATERI PRISMA DAN LIMAS KELAS VIII SMP NEGERI 1 PANDAAN TAHUN. 5, 27-34.

Firmiana, M. E., Al, U., Indonesia, A., \& Sisingamangaraja, J. (2014). Pengaruh Penggunaan Alat Peraga terhadap Hasil Pembelajaran Matematika pada Anak Usia Dini. 4, 297-305.

Munir, M., \& Sholehah, H. (2019). STRATEGI GURU DALAM PROBLEM BASED LEARNING UNTUK. 2(2), 103-108.

Nababan, S. A. (2020). ANALISIS KEMAMPUAN PENALARAN MATEMATIS SISWA. XI(1), 6-12.

Putri, D. K., Sulianto, J., \& Azizah, M. (2019). Kemampuan Penalaran Matematis Ditinjau dari Kemampuan Pemecahan Masalah. 3(3), 351-357.

Shofiyah, N., Sidoarjo, U. M., \& Reasoning, S. (2018). MODEL PROBLEM BASED LEARNING ( PBL) DALAM MELATIH SCIENTIFIC REASONING SISWA. 3(1), 33-38.

Syafrida. (2020). Bersama Melawan Virus Covid 19 Di Indonesia, 7(Covid 19). https://doi.org/10.15408/sjsbs.v7i6.15325

Wargadinata, W., Maimunah, I., Dewi, E., \& Rofiq, Z. (2020). Student's Responses on Learning in the Early COVID-19 Pandemic. 5(1), 141-153. https://doi.org/10.24042/tadris.v5i1.6153

Wicaksana, Y. (n.d.). Penalaran Matematis dan Kerja Keras Siswa Pembelajaran Matematika Berorientasi Teori APOS Berbantuan Permainan Monopoli. 305-311.

Yulianti, E., \& Gunawan, I. (2019). MODEL PEMBELAJARAN PROBLEM BASED LEARNING ( PBL ): EFEKNYA TERHADAP PEMAHAMAN KONSEP DAN BERPIKIR KRITIS PROBLEM BASED LEARNING ( PBL ) LEARNING MODEL : THE EFFECT ON UNDERSTANDING OF CONCEPT AND CRITICAL sejak dini. Selain berpikir kritis peserta dihadapkan dengan sejumlah materi yang proses pembelajaran itu sendiri. Banyak. 02(3), 399-408. 